\title{
Contemporary Art in the Regions of Russia: Global Trends and Local Projects
}

\author{
Dmitrii V. Galkin* \\ and Anastasiia Iu. Kuklina \\ National Research Tomsk State University \\ 36 Lenina Str., Tomsk, 634050, Russia
}

Received 21.04.2016, received in revised form 09.06.2016, accepted 19.08.2016

The authors deal with the problem of the development of contemporary art in the regions of Russia in the context of global projects and institutions, establishing 'the rules of the game' in the field of contemporary culture. The article considers the experience of working with contemporary art within the framework of the National Centre for Contemporary Arts and other organizations. So-called Siberian ironic conceptualism is considered as an example of original regional aesthetics. The article concludes that the alleged problem can be solved in the framework of specific exhibition projects and curatorial decisions, which aim at finding different forms of meetings (dialogue, conflict, addition) of a regional identity and global trends.

Keywords: contemporary art, National Center for Contemporary Arts, curatorial activities, regional art.

This article was prepared with the support of the Siberian Branch of the National Centre for Contemporary Arts.

DOI: 10.17516/1997-1370-2016-9-10-2413-2426.

Research area: art history.

The growing interest of researchers and the public in the dynamic trends and issues of contemporary art in Russia is inextricably linked with the development of various projects and institutions involved in the support of contemporary art not only in capital cities, but also in the regions. Suffice it to say that one of the most conservative art institutions of Russia, which is The State Hermitage Museum, not only fully dedicated the new area of the Admiralty building to contemporary art and was the organizer of one of the largest European Manifesto festivals, but also intends to open a profile branch in Moscow. But this is an example of the past three years. There are more historically important and longstanding examples. One of the brightest and most ambitious is the activities of the National Centre for Contemporary Arts (NCCA), which is a museum, exhibition and research organization and has seven branches in the regions of Russia. On March 25, 2013 the Siberian Branch of the NCCA was opened in Tomsk. During the two years of its existence, the SB of the NCCA organized and implemented many significant exhibitions

(C) Siberian Federal University. All rights reserved

* Corresponding author E-mail address: galkindv@me.com 
and educational projects with the participation of artists and international experts such as D. Bulatov, Guy Ben-Ari, E. Sherstoboeva, D. Pilikin, I. Chubarov, L. Bugaeva, D. Galkin and others. Several projects attracted attention in Russia and abroad. The exhibition Manifesto Trivia in 2013 was included in the shortlist of the prestigious All-Russian prize for contemporary visual art named Innovation, while the exhibition named Coincidence. Is there Russian Contemporary Art? in April 2014 was included in a parallel program of the European Biennial of Contemporary Art named Manifesta 10 in St. Petersburg. One of the main themes developed by the Siberian Branch of the NCCA is the study of contemporary art in Siberia and the Siberian identity. A largescale exhibition of Siberian artists named The United States of Siberia (11 July 2013) became a manifesto and the main project in this area. The curator Vyacheslav Mizin boldly declared the existence of the art movement called Siberian ironic conceptualism.

The activities of the Siberian Branch of the NCCA as a whole reflect the trend of the last decades that is active attempts to find a model of the development of modern art not only in capitals, but in regional cities as well. This trend is also reflected by the regional project Garage of the Centre for Contemporary Culture, and the large-scale project Perm - Cultural Capital of Russia. All initiatives have different fates. However, they all refer to the difficult culturological and art problem. In theoretical terms, the development of modern art in Russian regions deeply contradicts the situation, when this area of artistic life functions as an international global cultural mechanism associated with largescale institutions and festivals, famous artists and curators, art markets and global media, which define all the parameters of what contemporary art is. In practical terms, there is a problem of working out a strategy for the implementation of exhibition projects of contemporary artists in a regional context, which could lay claim to a voice in the world of contemporary art.

In this article we will try to develop these problems more fully and provide an analysis / study of the prospects for the development of contemporary art in Russian regions in terms of working out and implementing specific exhibition projects. In part, we are driven by the desire to fill the research void that now exists in this area.

If we sum up the basic theses that we will try to develop in terms of the stated problems, they may be as follows:

1. The work in the field of contemporary art in the regions of Russia is becoming a more active and widespread practice associated with the interests and activities of various institutions.

2. The development of contemporary art in the regions faces with the contradiction between the translation of the global international context (prestigious exhibitions, institutions, curators, auctions) and the search for distinctive regional (local) grounds.

3. This contradiction can be partly resolved in specific exhibition projects and curatorial decisions, which aim at finding different forms of meetings (dialogue, conflict, addition) of a regional identity and global trends.

\section{Problems and experience of regional contemporary art in Russia}

In the movie The Great Contemporary Art Bubble the British journalist and documentary filmmaker Ben Lewis calls the contemporary art the most bloated and most tenacious of all bubbles, explaining this statement by the fact that it fell short of expectations, largely thanks to the efforts of museums and became invulnerable, unlike other sectors of the economy ${ }^{1}$. Contemporary art is synthetic; it is woven from a variety of colorful threads, namely, literature, painting, 
music, the environment, the virtual space, etc. Therefore, modern art objects bear not only an aesthetic burden, but also are full of new ideas and meanings. The curator of the International Festival of Cybernetic Art in St. Petersburg Marina Koldobskaya compares contemporary art with the myth of the Tower of Babel. All languages mixed, several generations of artists, ranging from pop art, have been using the language of mass culture and politics, sociology and psychoanalysis, glossy photos and traditional painting, etc. ${ }^{2}$

This experimental artistic language was invented and is developing in the context of the European avant-garde of the early XX century and the ideology of modernism. In the $20 \mathrm{~s}$ of the XX century the Spanish philosopher and sociologist José Ortega y Gasset found a tendency towards dehumanization of art. He writes, “... the artist does not make mistakes. He deviates from 'the nature', from life-human values, from resemblance to them for a reason. The deviations indicate that he has chosen the path opposite to the one that leads to 'a humanized' object ... He aims at distorting the reality boldly, at breaking its human aspect, dehumanizing it" (Ortega y Gasset, 2000).

Indeed, in the fastest growing trends a piece of art itself disappears, the boundaries of things, meanings, practices, contexts blur. The artist makes anything a work of art, whether it is a rusty can, bottle glass or a garbage bag. Along with using various utilitarian items the action itself also becomes a piece of art. It is no coincidence that the growing audience and scientific interest in the dynamic trends and problems of contemporary art is increasing around actively conducted worldwide Biennials, festivals, exhibitions, conferences, museums.

But should contemporary art be notable, large-scale and global? Then it turns out that only events of the global level define what contemporary art is. Can we say that there is contemporary art in the regions, while various organizations provide a potential for its development?

In Russia, there are a number of institutions to deal with the problems of contemporary art. According to the authoritative art theorist Boris Groys, on the one hand, the number of museums of contemporary art is growing, money is invested in them, and they are advertised. On the other hand, such art institutions are currently being treated with suspicion. Groys writes, "The dynamic development of art institutions and, above all, contemporary art museums, takes place along with the process of erasing the obvious differences between manmade and technically produced things"'. Yet nowadays the museum is the last opportunity to distinguish true art from non-art. Therefore, we focus on the activities of such Russian cultural centers as the National Centre for Contemporary Arts (NCCA), GARAGE and the Museum of Contemporary Art PERMM. They are involved in supporting contemporary art, not only in Moscow but also in the regions, suggesting that this activity is an essential condition for the development of artistic culture in general.

The National Centre for Contemporary Arts (NCCA) is a museum, exhibition and research organization, whose activities are focused on the development of modern national art in the context of the global art process, the formation and implementation of programs and projects in the field of contemporary art, architecture and design in the country and abroad ${ }^{4}$. The NCCA is constantly expanding the geography of its activities and currently brings together the work of seven branches - in Kaliningrad, Vladikavkaz, Nizhny Novgorod, Yekaterinburg, Samara, Tomsk and St. Petersburg. It is the largest and most active regional network of institutions of contemporary art in Russia. 
The main activities of the branches include the introduction of modern art in the public space of the city, active educational, analytical, research, science and media activities, dynamic exhibition activities, art residencies, and a variety of experimental forms of work with artists and the audience. Each of the branches works on unique programs and projects aimed at the development and popularization of contemporary art in the region.

The Ural Branch of the NCCA, which started in 1999, implements the following programs: Artist-in-residence (Art residences - it is when invited artists implement projects in the branch); Art Research; Art. Science. Technology; Cultural Journalism; Education; Experiences of Interdisciplinarity; Cooperation; Ural Regions; Ural Plants: the Industry of Meanings. Besides, the Centre publishes the magazine of the creators and consumers of art named ZAART, which is currently trying to form a cultural geography of Non-Moscow. The Ural Biennale of Contemporary Art is deservedly considered the main and the most ambitious project of the Ural Branch. Among the permanent residents of the UB of the NCCA are such stars of Russian contemporary art as a street artist Timofei Radia and the group Where Dogs Run that is the brightest representative of Russian high-tech art.

The main program of the Baltic Branch of the NCCA includes Heritage in Actual Context; Modern Art and Contemporary Society; Modern Architecture, Spatial Development and Environmental Design; Art and Science in the Post-Biological Age; Audio and Video: the feedback; the exhibition program In the Attic; the program Artist in Residence; the educational program Art Classics (including the children and youth studio of digital art); the publishing program $p H$. The Baltic Branch regularly holds a popular festival of experimental music named Sound Around Kaliningrad, which became its trademark. In addition, thanks to the research and curatorial work of Dmitry Bulatov, the branch is unquestionably one of the leading development centers of the so-called science art in Russia.

The Volga Branch of the NCCA, which was opened in 1997 on the basis of the public organization The Nizhniy Novgorod Center for Contemporary Culture Cariatida is peculiar by the fact that it is the basis for a video archive and a video art collection. A cycle of telecasts Arsenal of Contemporary Art is based on them. Of great interest is the work on the artistic interpretation of the cultural heritage, which is implemented in the original exhibition projects (for example, the sensational project Below the Bottom in 2014). Another unique feature of the activities of Nizhny Novgorod is the development of educational programs for children and students. Today (after large-scale repairs) the branch is located in the Arsenal building in the territory of Nizhny Novgorod Kremlin and occupies an important place in the cultural landscape of the region.

The Northwest Branch of the NCCA in St. Petersburg was opened in 1995; in addition to the implementation of various artistic and cultural projects, it is engaged in the representation of foreign contemporary art in St. Petersburg and Russia, as well as Russian art abroad. A fairly well-known program of art residences (based in Kronstadt), which is closely linked with the work of the branch in the field of artistic experimentations in the urban environment, also functions here. In 2013 the residence was visited by 25 artists from Russia and 17 countries of the world. The final work of the artists were presented in the exhibition in the form of photographs, videos, installations, art objects, paintings and graphics that reveal the unique aura of the island-city, its history and modern lifestyle. Thus, the Kronstadt residence of the NCCA can be an example of the development of regional art projects outside the big city. 
Since 2010, the regional structure of the NCCA has expanded to the Caucasus. The new branch was launched in the city of Vladikavkaz and quickly attracted attention thanks to the forum Art Caucasus and the art symposium Alanika, combining exhibition, educational and research elements.

Speaking on the activities of the branches of the NCCA, we cannot but say that the architectural monuments received by the NCCA for the operational management to create the State Museum of Contemporary Art have been renovated and are being restored in different regions. For example, the restoration of the tower and part of the attic rooms of the barrack Crown Prince in Kaliningrad that is a historical and cultural monument of the XIX century is almost completed. In Nizhny Novgorod, the Arsenal building of the Nizhny Novgorod Kremlin was restored. Since May 1, 2015 after an extensive renovation, the new Arsenal has been open to the public. In Tomsk, they announced the beginning of the reconstruction of the building, in which the branch of the so-called Gorokhovsky warehouses of the architect Kryachkov on the banking of the Tom will be located ${ }^{5}$.

In our review the Siberian Branch of the NCCA has a special place, which is why we began our article exactly with it (see above). What is more, we will pay a special attention to it again.

The NCCA is not the only institution in the field of modern Russian culture. Its important feature is that there is a consistent and systematic work on the development of the branch system in the Russian regions that has already been conducted for more than twenty years. There is a complete institutional model that has developed and functions in the NCCA. But the same cannot be said about other examples of regionalization of contemporary art.

Let us refer to the regional ambitions of the Center for Contemporary Culture Garage.
It was founded in 2008 by Daria Zhukova in Moscow with a view to develop and promote contemporary culture. This independent cultural institution has a unique scientific archive, a vast exhibition program of Russian and foreign artists, educational and publishing activities, which form a high-quality environment to create new ideas and projects. In addition, Garage is engaged in the development and implementation of innovative methods of child and family education; the support of professionals in the field of art and culture. The activities of the Centre for Contemporary Culture Garage are not limited to holding capital exhibitions and festivals. On May 22-25, 2013 by demand of the Ministry of Culture of the Russian Federation the Centre held a seminar House of a New Culture: Designing the Future. It is easy to grasp the desire to reformat the traditional and customary provincial House of Culture and to find new and modern forms of functioning in the very title of the project.

The project of creating the Houses of a New CultureorHNCcenterswasaimedatdisseminating knowledge and advanced technologies in the field of culture and organization of life, as well as the creation of the environment conducive to creativity and self-realization of young people in cities with the population from 50,000 to 500,000 people (as opposed to the NCCA, branches of which are based in large regional centers). It was planned to build Pilot Houses of a New Culture in the cities of Kaluga, Pervouralsk and Vladivostok with the assistance of regional governments and private partners of the project ${ }^{6}$. And first of all experienced professionals in the field of contemporary art (including the NCCA), as well as contemporary artists from Russia, Europe and the United States were involved in their creation.

The essence of the Houses of a New Culture (HNC) was expressed by Alexander Oslon, the head of the fund Public Opinion, who said, "We truly believe that if there are conditions created 
for the development and self-realization of people, it will bear fruit"? The author of the article supports the point of view that the economic development is followed by the cultural demand. However, there were social groups of people who complained about the introduction of such modern houses of culture; they believed that if you are for a new culture, then you are against the old one. According to Anne Gor, the director of the Volga Branch of the NCCA, “... there are many people in the region who will tell you: we need no new culture, we will maintain the traditions."

Unfortunately, the project is closed and reformatted. In 2015, a special working group of the Ministry of Culture proposed not only to rename them in RCC - regional cultural centers - but also change their assignment dramatically, instead of contemporary art and cultural innovation, these institutions will be engaged in the patriotic and spiritual education of the residents of small towns?. As a result, the Garage will continue to fight for its rightful place in the global contemporary art scene (on their own new base in Moscow in Gorky Park) only as a capital institution.

Here we must return to our main question, which is shall we develop contemporary art in Russian regions? Is there really such a need? Modern art is a style of a new generation, it is consistent with the space in which the society currently resides. And this is a space of global cities. A good artist from the province can always go and succeed in the capital (like once they went to Paris to become a painter). The lovers of contemporary art can also visit the capital's festivals and exhibitions from time to time.

However, the international practice of cultural development suggests that contemporary art is actively moving to the regions. This happens in Europe (the competition Capital of Culture), and even in China. Contemporary art is becoming one of the resources of successful urban development (a well-known example is
Spanish Bilbao and the Guggenheim Museum). The problem of the lack of a cultural identity and cultural brand of various cities can be solved through the development of contemporary art in the region. It immediately impacts the city's attractiveness for investors, tourists and the socalled creative class. A high-quality cultural environment becomes extremely important for understanding the quality of life by the citizens themselves, which is not less important than attracting business and leisure travelers.

These bold and innovative projects involve risk and the possibility of failure. According to Charles Landry, "in most organizations, especially state ones, risk is disapproved, and failures are considered impermissible ... The fear of risk often means that organizations do not have the analytical mechanism to prevent future failures" (Landry, 2005).

And in this case a rather clear risk may be worth the award. All in all, the positive results of the activities of such cultural centers as the NCCA branches are obvious. They organize Russian and international exhibition projects of contemporary art, education and research programs, including a rich palette of cultural events such as festivals, lectures, master classes, art residences, which help to find a way to understanding contemporary art and develop, if not love for it, then, in any case, a taste for contemporary arts, an interest in them. This is not a question of abstract quality of life, but a very specific way to improve it, or at least to work on its improvement.

Here are just a few examples. In May, 2014 Tomsk hosted the annual exhibition project Street Vision. It is worth mentioning that this is a fullfledged event with a variety of genres including street art, music projects, contemporary art, photography and video art. The organizers aimed at the main inhabitants of Tomsk who are young students, and were able to attract about 7,000 thousand people. Contemporary artists 
were some of the main characters of the festival. Among them were street artists Timofei Radia and Pokras Lampas, the art groups Blue Noses and Where the Dogs Run. The main exhibition program of the festival in regard to contemporary art was formed by the Siberian Branch of the NCCA within a special project $I$ Feel $U$ with an active participation of students of the Institute of Arts and Culture of National Research Tomsk State University.

In 2012, the program of Art residences of the $2^{\text {nd }}$ Ural Industrial Biennale became a large-scale move of contemporary art outside the city of Yekaterinburg to Sverdlovsk Region. The project participants were seven artists from Russia, the USA and France. At first they had to get acquainted with the space of both existing and abandoned factories, explore the local industrial culture, create a project-study. As a result, their projects were supposed to actualize the problems and prospects of the local industrial context.

Concerning regional projects in the field of contemporary art, we cannot but turn to another eye-opening story. One of the largest and most successful projects of the Russian art critic, curator and gallery owner Marat Gelman is Cultural Alliance. Cultural Alliance brought together 17 cities that signed an agreement on exchange budgets. The objective of these cities is to organize a rich cultural life. It is impossible to do it only with the help of a city's own creators, therefore, the system of exchange of exhibitions between the cities was developed, which allows expanding and filling contemporary cultural space with new talents. Gelman proceeded from the fact that the artistic environment in Russia is very small, and the main task of this project should be its dramatic expansion, or the transformation of the Moscow art scene in Russia that is even more ambitious ${ }^{10}$.

To do this, Marat Gelman himself decided to move to Perm and there on site attempted to run the international project Perm - Cultural Capital at the regional level as the director of the Museum of Contemporary Art PERMM ${ }^{11}$. The main idea of the project is that culture can and should play a key role in the socio-economic development of the region. It was announced at the $5^{\text {th }}$ Economic Forum in Perm in 2009 and was endorsed by the governor of the region and the Federation Council $^{12}$. The pragmatic side of turning Perm into a cultural capital was based on the desire to create a more comfortable environment in the region by cultural means for young people who mostly go from Perm to Moscow and Yekaterinburg.

In Perm region the project caused a huge negative response. The conflicts in 2013 caused the resignation of Marat Gelman from the position of the director of the museum PERMM, and the fate of large-scale projects such as Cultural Alliance, Perm - Cultural Capital was put into question. As a result, they were stopped by the authorities of the region. However, the Museum of Contemporary Art continues to work successfully.

Thus, one of the problems of development of contemporary Russian art is that single groups and specific individuals are interested in the effort to improve the cultural situation in the region. Being in conflict relations with the political elite, they are unable to resist the dominant structure. In the interview to the magazine Vozdukh in 2014, Gelman expressed a controversial statement that currently in Russia everything is moving to the situation that once again, like it was in Soviet times, art will be divided into formal and informal, and this will have a detrimental impact on the entire Russian cultural area ${ }^{13}$.

Therefore, on the one hand, it is the work in the regions of such institutions as the National Center for Contemporary Arts, the Center for Contemporary Culture Garage, Museum of Contemporary Art PERMM that can guarantee and stimulate the expansion of the modern Russian culture in the regional context. But 
this is only the institutional aspect of the issue. Bringing famous Western artists to the province does not mean developing modern art. And then there is a following question, can the distinctive regional aesthetics develop and be viable outside the capital?

\section{Aesthetics of Siberian ironic conceptualism}

The Siberian Branch of the NCCA is trying to work under the slogan of a search for a regional individuality and identity. Here Siberian ironic conceptualism may be an example of regional aesthetics. It begins with the question of whether there are any special Siberian features impregnated with "Intolerable Siberian frosts, unbearable Siberian penal servitude, innumerable natural resources ..." (The United ... 2014). Siberian art is a complex and poorly studied phenomenon. The interviews with Siberian artists and the catalog of the exhibition The United States of Siberia published by the Siberian Branch of the NCCA in 2014 are some of the existing attempts to describe (or fabricate?) the aesthetics of contemporary art in Siberia.

One of the heroes in the struggle for identity is Alexander Shaburov (Russian artist, member of the art group Blue Noses). In the article The Biography of the Most Famous Artists of Novosibirsk and the Retelling of Their Works, he argues that Siberian features do not exist. "There is no difference between Siberians, Uralians, and inhabitants of the Far East" (The United ..., 2014). A distinctive feature of Siberian art is that all the artists here are spontaneous Eurasian medium peasants, treating people with a different point of view calmly, regardless of their national origin, making Siberian savages of themselves with pleasure." Siberian artists have a similar role; all of them are "nuggets and mockers." The function of their art is to test the strength of popular culture, to mock and parody it. And the essence of the
Siberian art is conservatism and protection "from the globalization of consciousness and myths of metropolitan media" (The United ... 2014).

But first, let us turn to the history of the formation of modern Siberian art, which began to take shape in the mid 80 s of the XX century and is associated with a number of names. That was the period when 'paper architects' and 'underground artists' Vyacheslav Mizin, Maxim Zonov and Dmitriy Bulnygin began to engage in artistic activities. They organized the first exhibition named Souls of Workers in 1990 at the plant of metal structures. In 1995, Mizin, who called his method art dementia, and Bulnygin, who subsequently oversaw the international competition Festival of Ultrashort Movie, went to Zurich for the festival Eurokot, where they got acquainted with the artists from Yekaterinburg, namely with O. Elovyi and A. Golizdrin. There was a sufficiently developed cultural community in Ekaterinburg, the whole galaxy of remarkable characters, such as the legendary Uktus School (led by Anna Tarshis), B.U. Kashkin (the founder of Obshchestvo Kartinnik), Vladimir Zhukov (the founder of Okkazional Art), Evgenii Arbenev (the inventor of subconscious graphics) and others.

The end of the 1990s is characterized by the flourishing of Novosibirsk contemporary art thanks to the support of the Soros Foundation. In 1999, the extreme art festival Beyond Time Shelter was organized by Novosibirsk artists with the assistance of the Fund of Kondratiuk. Artists from Poland, Ukraine, Slovenia, Georgia and Russia decided to celebrate the New Year, shutting up for a few days in the shelter. The purpose of the festival is to come up with innovative art in the absence of high technologies. Thanks to this event, the group Blue Noses appeared. Vyacheslav Mizin and Alexander Shaburov become an art group consciously in 2003 at the Triennale in Vilnius. In 2002 they took part in the Biennale in Cetinje (Montenegro), and then 
there was the Venice Biennale, the $1^{\text {st }}$ Moscow Biennale of Contemporary Art, and others. Thus, the artists who created their 'populist' option of Contemporary Art, based on today's Internet folklore and images of mass culture, became some of the most famous and provocative in the country. There is no univocal attitude to the creative work of the art group. The Ex-Minister of Culture Aleksandr Sokolov called their work a shame of Russia.

In general, Aleksandr Shaburov notes that there are no specifics of the modern culture of Siberia as such for several reasons. The professional community has formed relatively recently, institutions opened due to the activity of enthusiasts, which is the reason of their fragility. In this regard, local artists of contemporary art have a complex or creative inferiority or a complex of Dunno. Despite the differences and so-called identity, the artistic score from the outside, better from the capital, was extremely important. Anyway, it takes extraordinary research and artistic work for the analysis and development of the current situation (The United, ... 2014).

The very resonant exhibition The United States of Siberia (11 July 2013, curated by V. Mizin) was an attempt of this study. The exhibition brought together artists who created in different spaces of the vast Siberia (Novosibirsk, Krasnoyarsk, Omsk, etc.). The curatorial and creative solutions are inextricably linked to Cultural Alliance of Marat Gelman and aesthetics of 'the Russian poor', which served as its basis.

The United States of Siberia combined the creativity of Vasiliy Slonov from Krasnoyarsk with his parody posters for the Sochi Olympics Welcome to Sochi - 2014, Damir Muratov from Omsk with a series of works If They Had Been Born in Siberia ...., the photo-works of different years of the Novosibirsk group Blue Noses and the creativity of Sergei Bespamyatnykh with a series of works They Fought for Their Country,
Konstantin Eremenko with a series of Hystory of Siberia, History of the Siberian Epic Guerrilla Separatist Lykov, the works by Igor Sherko Being a Man, the works of photo artists of the group TRIVA, the photo works by Evgeniy Ivanov Homo Demonstraticus and others.

This exhibition became a manifesto, the application for the existence of such an art movement as Siberian ironic conceptualism. What does this mean from the point of view of art? We think that, firstly, conceptualism suggests that the artist is interested not so much in an art form as in the content side of artistic expression, breaking through the provocative gestures of the author and addressing to the multilayer reading by the public. Secondly, Siberian ironic conceptualism is close to that direction in contemporary art, which is associated with the techniques of pop art and arte-povera on topics and material. After the end of the exhibition project a catalog was published. Thus, the artistic phenomenon was documented and officially presented.

In Riga (the cultural capital of Europe in 2014) the exhibition On the Wave representing the contemporary art of Latvia and Siberia was successfully opened in mid-June. The exhibition was organized by the Latvian Institute of Contemporary Art, the Siberian Branch of the National Centre for Contemporary Arts and the Novosibirsk Foundation Siberian Center for Contemporary Art. The backbone of the team of Siberia on contemporary art was made by the authors, well-known for the exhibition The United States of Siberia, such as Damir Muratov (Omsk), Vasiliy Slonov (Krasnoyarsk), the group Blue Noses (Novosibirsk - Moscow), Dmitry Bulnygin (Moscow - Novosibirsk), Konstantin Eremenko, Sergei Bespamyatnykh, Igor Sherko, Konstantin Skotnikov (Novosibirsk). All of these artists were presented both by already known and brand new works, some of which had been specially created for the exhibition On the Wave. 
The autumn issue of the Russian edition of Rigas Laiks published an interview with Vyacheslav Mizin, the director of the Siberian Branch of the NCCA and an artist from the group Blue Noses. During the interview he discussed the Siberian identity as well. According to Mizin, there is some Siberian sincerity, "It seems to be done wholeheartedly, especially at first ...". Asking the question, whether the Siberian art is collective, the curator said,

"... When I came down to that seriously, I found out that they all have a special view of things. For me it is ironism, criticism, a certain absurdity. And I did not have to take any special steps to unite the artists under any slogan ... Siberian art is such a pool of artists who think about things in the same way and work almost identically." "14

The theme was continued by other exhibition projects on the basis of the SB of the NCCA. On October 9, 2014 in the Siberian branch of the NCCA within the round table Modern Art Made in Siberia: what is it? the organizers held a press opening of the exhibition My Kremlin of the artist Natasha Yudina from Tomsk. The young, but already well-known artist decided to take advantage of many details in the form of a toy Kremlin, getting attention to the idea what homeland is with a very simple, everyday and intimate-material perspective? During the round table the participants discussed such complex and contradictory things, as modern Siberian art and its presentation to different audiences.

The discussion was focused on the contradiction stated by us in the beginning of this article. Someone claimed that the modern Siberian art, of course, exists, despite the fact that at the moment the Siberian identity is strongly suppressed. Someone said that art made in Siberia is guided by certain international 'norms', methods and techniques, and is not Siberian by its roots. For some people the tradition, which was founded in the Siberian punk in the mid-80s, is a sample of Siberian art. Answering the question, whether Natasha Yudina associated herself with such Siberian artists as D. Muratov, V. Slonov, the group Blue Noses and with the national tradition of contemporary art, the artist said:

"Of course, I feel some sameness of thought. As for the Siberian identity, I do not dare to study it specifically, but it still somehow ... 'creeps out'. With regard to contemporary art I can say this ... I feel sorry, that art is divided into two camps - the new and the old. The new does not mean that it is only due to imposed, totalitarian management. However, contemporary art is rather totalitarian. Just the time has come when the old forms are not enough, we need a concept, ideology, the ability to 'turn on' brains, but not only to contemplate the beauty."'15

Another important exhibition project was implemented in April 2015. The documentary exhibition entitled Review of the Unstudied explores the context of the Siberian art of the 1990s (the curator was S. Samoylenko). In the early 90s in Novosibirsk (PAN Club), Tomsk (Maks Baturin) and Kemerovo (Maks Ukolov and the Lodge theatre) independent artistic movements, synthesizing literature, theater and visual art, practicing artistic interventions in the urban environment in the form of performances appeared. The practice of these movements largely repeated the art movement FLUXUS, although Siberian artists and writers could hardly guess it. The artists of Fluxus during the existence of the movement tried to avoid the usual artistic institutions; trying to destroy the very principles of art, they held happenings, performances, were engaged in video art, avantgarde poetry, worked in the aesthetics of 'a thing', 'an object'. The basic principle of the movement was absolute spontaneity, randomness, waiver of any restrictions ${ }^{16}$. As an example, we can mention the action on the Black River (70 km to 
the south of Novosibirsk), organized on February 14, 1994 jointly by the newspaper Young Siberia (in the person of the head of the PAN-club) and the Drama Theatre Molodezhnyi (directed by Sergey Afanasiev). The purpose of the action was to restore historical justice. The participants performed a ritual in which Pushkin took revenge on his abuser over 157 years after the defeat in the duel ${ }^{17}$.

This story can be seen as an illustration of the fact that it was in the 90s of the last century when the parameters were laid and the vector of the further development of contemporary art in Siberia was set, and the members of those movements became key players in different fields, such as visual arts, literature and theater.

Thus, through a series of exhibitions dedicated to the Siberian identity, Siberian ironic conceptualism declared itself as a special artistic phenomenon, which exists in a regional context. We also see an attempt to create an art brand, attracting attention to the Siberian art in general. Here we also see the desire of Siberian artists to indicate their otherness and identity in the Russian and international art scene. A. Shaburov in his introduction to the catalog The United States of Siberia arrives at the following idea, “...Siberian artists harp on Siberian features not because they are separatists and follow the crafty American plan of colonization of Siberia under the guise of 'human rights' and the imposition of 'contemporary art', but because they are skeptical about any memes and hashtags getting across to them. They do not fall under media planning, zombieing and manipulation, preferring a direct communication" (The United ..., 2014).

That is how a reflex of resistance to any outside pressure triggers. It results in the manifestation of the characteristic features of Siberian art, such as edginess, reflection to the social and political events, the study of home and daily life, selfirony, anecdotalism and, what is more important, a partly doomed and unexpectedly fascinating attempt to explore the phenomenon of Siberian features by modern culture means.

So, in this example we can see that not only and not so much artists themselves try to create the regional aesthetics. The key role here is sooner given to the curatorial work. Here we mean the curator, who comprehends, formulates a concept and launches a project. How far can the figure of the curator become a kind of bridge between a regional project and the global context? After all, according to the apt remark of Boris Groys, curating means 'healing',

"The process of curating heals the importance of a product, its inability to show itself to the world. Works of art need someone else's help, and they need an exhibition and a curator to be seen" (Groys, 2013).

On the one hand, any interference of the curator looks suspicious because he seems to be a kind of insidious figure, manipulating the perception of the viewer in order to deprive them of a personal artistic experience. Despite the fact that in the process of the organization of the exhibition, the curator inevitably comes to some relativization, his work is not 'a zero-creative act'. This figure is the driving force, due to which the birth of a historically important artistic event and the very definition of art become possible. The logic here is simple and meaningfully related to the problem of determining what a work of art is and why,

"The old question should be asked anew: what is a work of art? Contemporary art practices give a fairly unambiguous answer, namely, a work of art is an exhibited object. It means, an unexhibited object is not a work of art, but only a thing which can potentially become it. We do not casually talk about 'contemporary art'. Such art must be demonstrated in order to be seen. Thus, the basic unit of art today is not a separate product, but the exhibition space. Contemporary 
art is not a number of things, but the topology of certain spaces" (Groys, 2013).

These ideas are differently developed by the art historian and director of the London gallery Serpentine Hans-Ulrich Obrist, who notes that the curator today is understood as a person who "brings together various cultural spheres, inventing new methods of demonstration and creates new crossing points where unexpected perspectives and new results appear." 18 Victor Miziano, the famous Russian art critic and curator, emphasizes that a curator is a mastermind and creator of an exhibition art project, which means he is a co-author.

"From now on the exhibition organizer is not any more an expert or a research scientist who builds exposition rows of the finished works, following these or those scientific methods. Today, he is rather a bearer of living knowledge. The cognitive value of his activity is born out of the elements of a creative dialogue with the artist, and the product he created is not so much an exposition show in the strict sense of the word, as an exhibition event" (Miziano 2014).

Different authors agree that since the middle of the XX century the exposition has become a subject of critical reflection, while the organization of the exhibition has become a project work, acquiring the character of the author. Now the field for curatorial work has formed. It is evolving and becoming more complex. There are curators working in various institutions (museums, galleries, contemporary art centers), and accordingly, depending on the cultural policy pursued by the art institution. And there are so-called independent curators, who are able to work in changing institutions with the choice and freedom in the implementation of various art projects. In any case, the logic of curatorial activities includes a mandatory set of tasks:

- To develop and approve of the concept of the exhibition together with the head of the museum or art-platform (it is important to remember that the concept is a basic text which should contain a succinct justification of artistic ideas);

- To search and select the particular exposure material, to decide where to place it in the exhibition space, as well as to coordinate the work with the designers of the exposition and printing;

- To control and coordinate the mounting;

- To form a strategy of promotion of the exhibition, its representation to the public, dealing with the media, the guests;

- To plan and implement an educational program at the exhibition (curators are often lecturers);

Thus, such institutions as the National Center for Contemporary Arts, the Centre for Contemporary Culture Garage, the Perm Museum of Contemporary Art PERMM deal with the problems of the development of the regional art. Of course, their work is very important for the development of the country's artistic culture as a whole. A striking example of the regional contemporary art is the phenomenon of Siberian ironic conceptualism, which is a kind of a Siberian art brand, supported by the Siberian Branch of the NCCA (Tomsk). Finally, the driving force behind the development of contemporary art is a curatorial practice. Therefore, today international and regional art projects are created thanks to the work of curators.

\section{Conclusion}

Summing up, I would like to draw some conclusions regarding the stated issues. We are convinced that the development of contemporary art in Russian regions depends largely on the activities of various institutions that have human resources and tools to work in the regions. On the one hand, the work of these cultural organizations (the NCCA, Garage) now can be the foundation for the formation and development of modern 
Russian culture. On the other hand, there are some doubts about the fact that the original regional aesthetics can develop independently and be viable outside the capital and international art laws.

If we consider the problem on the basis of works of Siberian artists as an example of regional aesthetics of Siberian ironic conceptualism, referring to the history of the formation of modern Siberian art, in this logic, we are forced to come to the analysis of the exhibition projects implemented, in particular, in the Siberian Branch of the National Centre for Contemporary Arts (the NCCA). Our analysis suggests that the Siberian regional aesthetics develops due to specific curatorial decisions and ambitions, which are directed to the regional and the international context.

If the original and essential aesthetics is not only a product of the artist, but also of a curator, who comprehends, formulates a concept and launches a project, it is exactly within a specific curatorial project, where an opportunity to address the problems we stated emerges.

The authors of the study were able to see it themselves, working on the preparation of the exhibition My Kremlin of the Tomsk artist Natasha Yudina. Today, any exhibition project is the result of collective work, calling into question the traditional authorship of the individual artist. 'Multiple authorship' is the name of this phenomenon given by Boris Groys. For major exhibitions it turns out to be quite akin to a complex collective theatrical production, film production, organizing a music concert or recording a music album. Producers, directors, musicians, writers, actors, cameramen are all the co-authors! (Groys, 2013)

Thus, returning to the ideas stated in the article, we, on the one hand, made sure that the development of contemporary art in the region faced with the contradiction between the translation of the global international context (prestigious exhibitions, institutions, curators, auctions) and the search for distinctive regional (local) grounds. However, our findings show that this contradiction can be partly resolved in specific exhibition projects and curatorial decisions, which aim at finding different forms of meetings (dialogue, conflict, addition) of a regional identity and global trends.

The film The Great Contemporary Art Bubble. Available at http://www.artcontext.info/art-video/88-film-about-art/1146bubble.html

The International Festival of Cybernetic Art. Available at http://www.cylandfest.com/files/Cyberfest2011-catalog.pdf

3 Groys, B. O muzee sovremennogo iskusstva [About the Museum of Modern Art]. In Khudozhestvennyi zhurnal [Art Magazine], 23. Available at http://www.guelman.ru/xz/362/xx23/x2307.htm

4 National Center for Contemporary Arts. Available at http://www.ncca.ru/articles.text?filial=2\&id=11

Ibid.

Museum of Contemporary Art Garage. Available at http://garageccc.com/ru/page/about

Novosti Kalugi [News of Kaluga]. Available at http://kaluga24.tv/pravda-o-dnk-zachem-kaluge-i-rossii-nuzhna-novaya-kultura/

Ibid.

ART 1. Visual daily. Available at http://art1.ru/zloba-dnya/proekt-domov-novoj-kultury-svernuli/

Youtube (video hosting service). Available at http://www.youtube.com/watch?v=-xidM4eJD5s

Cultural Alliance Gallery. The project by Marat Gelman. Available at http://www.guelman.ru/

Snob (magazine). Available at http://snob.ru/chronicle/entry/6294

Vozdukh [Air] (magazine). Available at : http://vozduh.afisha.ru/art/marat-gelman-teper-ya-zanimayus-proektami-ne-v-rossii/ Rīgas Laiks (the Russian edition). Autumn, 2014.

15 The National Center for Contemporary Arts in the social networking service Vkontakte. Available at https://vk.com/ club67130776

16 Fluxus. Available at http://visart.info/POST/flux.htm

17 Novaia sibirskaia gazeta "Molodaia Sibir"”. [New Siberian newspaper Young Siberia], 7 (14), February 19, 1994.

18 Obrist, H.-U. Kuratorstvo. Kak borot'sia s pereproizvodstvom i pereraskhodom resursov, kotorye zakhlestnuli mir [Curatorial Work. How to Deal with Overproduction and Overuse of Resources, which Swept the World]. Available at http:// esquire.ru/ideas/hans-ulrich-obrist 


\title{
References
}

Groys, B. (2013). Politika poetiki [Poetics Policy]. Moscow, Ad Marginem, 400 p.

Landry, Ch. (2005). Kreativnyi gorod [Creative City]. Moscow, Klassika-XXI, 399 p.

Miziano V. (2014). Piat' lektsii o kuratorstve [Five Lectures on Curatorial Work]. Moscow, Ad Marginem, $256 \mathrm{p}$.

Ortega y Gasset, J. (2006). Degumanizatsiia iskusstva [Dehumanization of Art]. Moscow, Raduga, $646 \mathrm{p}$.

Soedinennye Shtaty Sibiri. Sibirskii ironicheskii kontseptualizm [The United States of Siberia: Siberian Ironic Conceptualism], in Katalog vystavki [The Exhibition Catalog]. (2014). Tomsk, Siberian Branch of the National Center for Contemporary Arts, 238 p.

\section{Современное искусство}

в регионах России:

глобальные тренды

и локальные проекты

\author{
Д.В. Галкин, А.Ю. Куклина \\ Национальный исследовательский Томский \\ государственный университет \\ Россия, 634050, Томск, пр. Ленина, 36
}

\begin{abstract}
Авторы обращаются к проблеме развития современного искусства в регионах России в контексте глобальных проектов и институичии, устанавливающих «правила игры» в области современной культуры. Рассматривается опыт организации работы с современным искусством в рамках деятельности Государственного иентра современного искусства и других организаиий. В качестве примера оригинальной региональной эстетики рассмотрен так называемый сибирский иронический концептуализм. Делается вывод, что заявленная проблема может решаться в рамках конкретных выставочных проектов и кураторских решений, которые направлены на поиск различных форм встречи (диалог, конфликт, дополнение) региональной самобытности и глобальных трендов.
\end{abstract}

Ключевые слова: современное искусство, Государственный центр современного искусства, кураторская деятельность, региональное искусство.

Статья подготовлена при поддержке Сибирского филиала Государственного иентра современного искусства.

Научная специальность: 17.00.00 - искусствоведение. 